\title{
Final classification of Bisgaard taxon 9 as Actinobacillus arthritidis sp. nov. and recognition of a novel genomospecies for equine strains of Actinobacillus lignieresii
}

\footnotetext{
${ }^{1}$ Department of Veterinary Microbiology, The Royal Veterinary and Agricultural University, 4 Stigbøjlen, DK-1870 Frederiksberg C, Denmark

2 Danish Veterinary Laboratory, Bülowsvej 27, DK-1790 Copenhagen V, Denmark
}

\author{
Henrik Christensen, ${ }^{1}$ Magne Bisgaard, ${ }^{1}$ Øystein Angen ${ }^{2}$ \\ and John Elmerdahl Olsen ${ }^{1}$ \\ Author for correspondence: Henrik Christensen. Tel: +45 35282783. Fax: +4535282757. \\ e-mail: hech@kvl.dk
}

\begin{abstract}
Phenotypic characterization of bacteria from diseased and healthy horses identified 18 isolates as Bisgaard taxon 9 and 11 isolates as Actinobacillus lignieresii. All strains of taxon 9 were $\alpha$-galactosidase- and raffinose-positive and showed variable fermentation of $(+)$ L-arabinose and $(-)$ D-sorbitol. Strains of $A$. lignieresii were negative for these characteristics, with the exception of raffinose. Two strains from the (-)D-sorbitol-negative group of taxon 9 showed a 165 rRNA similarity of $99.6 \%$, while $99.5 \%$ similarity was found between two strains of the (-)D-sorbitol-positive group. DNA-DNA hybridization between the two strains representing the (-)D-sorbitol-negative group showed $98 \%$ binding, and their closest relationship was to a strain of $A$. lignieresii $(64 \%)$. The two strains of the (-)D-sorbitol-positive group showed $83 \%$ binding and were related to the (-)D-sorbitol-negative group at a $76 \%$ DNA binding level. Actinobacillus arthritidis sp. nov. is proposed for 12 strains of the (-)D-sorbitolpositive group. Actinobacillus genomospecies 2 is suggested for the six strains of the (-)D-sorbitol-negative group. Phenotypically, strains of A. arthritidis and Actinobacillus genomospecies 2 differ in (-)D-sorbitol fermentation and can be separated from Actinobacillus equuli by being trehalose-negative, while a positive reaction for $\alpha$-galactosidase separates the taxa from $A$. lignieresii. The type strain of A. arthritidis, CCUG $24862^{\top}$, was isolated from a joint of a horse. Three equine isolates of $A$. lignieresii that could not be separated from the type strain by means of phenotypic characteristics showed 98.6-100\% $16 \mathrm{~S}$ rRNA similarity, but only $96.4-96.7 \%$ similarity to the type strain. DNA-DNA hybridization between two strains of this group showed $92 \%$ binding but only $70 \%$ binding to the type strain of $A$. lignieresii. Consequently, these equine isolates of $\boldsymbol{A}$. lignieresii represent a new genomospecies of Actinobacillus, suggested as genomospecies 1 because phenotypic characteristics are not presently available to separate it from the type strain of $\boldsymbol{A}$. lignieresii.
\end{abstract}

Keywords: Actinobacillus arthritidis, Actinobacillus lignieresii, Bisgaard taxon 9, genomospecies, horse

\section{INTRODUCTION}

The redefinition of Actinobacillus sensu stricto has been discussed recently (Bisgaard, 1995). Mutters et al.

A table showing the DNA-DNA binding matrix is available as supplementary material in IJSEM Online (http://ijs.sgmjournals.org/).

The GenBank accession numbers for the $16 \mathrm{~S}$ rDNA sequences of strains CCUG 24862 ${ }^{\top}$, F 141, H 4272/4, F 127, F 264 and 13/225/95 are respectively AF247712, AF247717, AF247719, AF247722, AF247723 and AY029174.
(1989) suggested that the genus be limited to include Actinobacillus lignieresii, Actinobacillus pleuropneumoniae, Actinobacillus equuli, Actinobacillus capsulatus, Actinobacillus suis, Actinobacillus ureae, Actinobacillus hominis and Bisgaard's taxa 5,9 and 11. With the exception of A. capsulatus and Bisgaard's taxa 5 and 9, this was confirmed by $16 \mathrm{~S}$ rRNA sequencing (Dewhirst et al., 1993). For the present study, Actinobacillus sensu stricto has been restricted to include $A$. equuli, $A$. hominis, A. lignieresii, A. pleuropneumoniae, A. suis, $A$. 
ureae and Bisgaard's taxa 8, 9 and 11, excluding $A$. capsulatus, Actinobacillus delphinicola, Actinobacillus indolicus, Actinobacillus minor, Actinobacillus muris, Actinobacillus porcinus, Actinobacillus scotiae, Actinobacillus seminis and Bisgaard taxon 5, since these taxa do not form a consistent monophyletic group with the first nine taxa on the basis of 16S rRNA sequence comparison (Dewhirst et al., 1993; Foster et al., 1996, 1998).

Among the true species of Actinobacillus, A. lignieresii, $A$. equuli and Bisgaard's taxa 9 and 11 have been isolated from horses (Bisgaard, 1993). Other equine taxa belonging to Actinobacillus may exist (Blackall et al., 1997; Sternberg \& Brändström, 1999). These organisms are of clinical importance to both the veterinary and medical professions, since they may cause disease in horses and may be found in infected wounds of humans bitten by horses (Dibb et al., 1981; Peel et al., 1991; Ashhurst-Smith et al., 1998).

Equine strains of organisms described previously as $A$. suis, or haemolytic variants of $A$. equuli, were classified as taxon 11 by Bisgaard et al. (1984). Subsequent investigations have confirmed the existence of taxon 11 and have shown that haemolytic strains of so-called $A$. lignieresii in horses have a whole-cell PAGE profile that is different from that of the bovine reference strain (Jang et al., 1987; Samitz \& Biberstein, 1991). Among the horses examined by Ward et al. (1998), lowerairway inflammation was associated significantly with taxon 11-like bacteria and A. lignieresii. 16S rRNA sequencing and DNA-DNA hybridizations have recently shown that $A$. equuli and Bisgaard taxon 11 represent two genotypes with different disease patterns and epidemiology (Christensen et al., 2002).

A single horse-joint isolate (Wetmore $1706^{\mathrm{T}}=\mathrm{CCUG}$ $24862^{\mathrm{T}}$ ) received as $A$. equuli and identified phenotypically as $A$. equuli unexpectedly remained unclassified by DNA-DNA hybridization according to Escande $e t$ al. (1984). This strain was subsequently found to be identical to organisms obtained from the mucous membrane of the oropharynx in apparently normal horses in Denmark and tentatively designated as taxon 9, since they could be separated from A. equuli sensu stricto by means of differences in trehalose fermentation (Bisgaard, 1993). Taxon 9 has been obtained from diseased horses in Australia (Blackall et al., 1997), Zimbabwe and Sweden (M. Bisgaard, unpublished).

A. lignieresii is normally associated in ruminants with pyogranulomatous lesions of the tissues of the upper alimentary tract and its draining lymph nodes (Biberstein, 1981). In addition, A. lignieresii can be obtained from the oropharyngeal mucosa and rumens of these animals (Bisgaard et al., 1986). In horses, A. lignieresii has been isolated from an epidural abscess (Chladek \& Ruth, 1976), an intermandibular phlegmon (Zaharija et al., 1979), an enlarged tongue (Baum et al., 1984) and in cases of stomatitis (Bisgaard, 1993). These organisms can also be obtained from the cavum oris in apparently normal horses (Bisgaard, 1993). Although phenotypic variations have been reported for $A$. lignieresii, all bovine strains investigated fell into a single DNA hybridization group (Escande et al., 1984). However, genetic investigations published so far have not included equine strains of $A$. lignieresii.

The aim of the present study, therefore, was to investigate the phylogenetic relationship between the bovine and equine isolates of $A$. lignieresii and to define the genetic borders of Bisgaard taxon 9 in order to be able to name this taxon.

\section{METHODS}

Bacterial strains and phenotypic characterization. The selection of strains (Table 1) was based on previous investigations (Dibb et al., 1981; Peel et al., 1991; Blackall et al., 1997, 1998) and strains maintained in our laboratory. Phenotypic characterization was performed as reported previously (Bisgaard et al., 1991; Angen et al., 1997). For further genotypic characterization, four strains of Bisgaard taxon 9 were selected to represent differences in $(+) \mathrm{L}$-arabinose, $(-)$ D-sorbitol, maltose and $(+) \mathrm{D}$-melibiose fermentation, source of isolation and geographical location. Three strains of $A$. lignieresii were selected to represent horse-associated isolates as well as isolates from horse bites of humans.

Serotyping. Equine isolates of A. lignieresii were serotyped using rabbit antisera raised against reference serotypes of A. pleuropneumoniae, using a latex agglutination test (Giese et al., 1993).

Sequencing of 16S rRNA genes. Bacteria were cultured overnight in brain-heart infusion broth (Difco) at $37^{\circ} \mathrm{C}$. One $\mathrm{ml}$ culture was harvested by centrifugation and DNA extraction was performed according to Leisner et al. (1999). PCR amplification was performed as described by Vogel et al. (1997). Oligonucleotides for both PCR amplification and sequencing were synthesized according to the sequences and $16 \mathrm{~S}$ rRNA positions given by Paster \& Dewhirst (1988) and Dewhirst et al. (1989). PCR-amplified fragments were purified in Microspin columns (Amersham Pharmacia Biotech) and then cycle-sequenced (Thermo Sequenase fluorescent labelled primer cycle sequencing kit; Amersham Pharmacia Biotech) in an ALF sequencer (Amersham Pharmacia Biotech), using fluorescein-labelled primers.

Analysis of sequence data. Searches for $16 \mathrm{~S}$ rRNA sequences were performed with FASTA and BLAST, using the Wisconsin sequence analysis package (Genetics Computer Group). Sequences were aligned and numbered according to the Escherichia coli $16 \mathrm{~S}$ rRNA $r r n B$ sequence. The region covering positions 28-1480 ( $E$. coli numbering of $r r n B$ ) was aligned and 1374 positions remained after the removal of ambiguous positions (95 distinct data patterns were analysed). Maximum-likelihood analysis was performed by using fastDNAml including bootstrap analysis (Felsenstein, 1981; Olsen et al., 1994). Parsimony and neighbour-joining analyses were performed using PHYLIP (Felsenstein, 1995).

DNA-DNA hybridization. DNA similarities were determined according to the micro-well method (Christensen et al., 2000). 
Table 1. Strains investigated in this study

\begin{tabular}{|c|c|c|c|}
\hline Strain & Source & Country & Reference \\
\hline \multicolumn{4}{|l|}{ Actinobacillus arthritidis sp. nov. (taxon 9) } \\
\hline $\begin{array}{l}\text { CCUG } 24862^{\mathrm{T} *} \\
\left(=\text { Wetmore } 1706^{\mathrm{T}}=\text { ATCC } 13376^{\mathrm{T}}=\mathrm{P} 907^{\mathrm{T}}\right)\end{array}$ & Horse, joint & Czech Republic & Escande et al. (1984) \\
\hline F 129 & Horse, cavum oris & Denmark & \\
\hline F 185 & Horse, cavum oris & Denmark & \\
\hline F 268 & Horse, cavum oris & Denmark & \\
\hline F 453 & Horse, cavum oris & Denmark & \\
\hline G $6562 / 4$ & Horse lung, septicaemia & Australia & Blackall et al. $(1997,1998)$ \\
\hline I $5445 / 5$ & Horse brain, septicaemia & Australia & \\
\hline $13 / 225 / 95^{*}$ & Horse, joint & Zimbabwe & Mohan et al. (1997) \\
\hline KLM 91-229 & Foal, sepsis & Sweden & M. Bisgaard (unpublished) \\
\hline KLM 96-448 & Foal, sepsis & Sweden & M. Bisgaard (unpublished) \\
\hline CEH 14-99 & Horse, oral cavity & Sweden & M. Bisgaard (unpublished) \\
\hline Bd 937-94 & Diseased foal & Sweden & M. Bisgaard (unpublished) \\
\hline \multicolumn{4}{|l|}{ Actinobacillus genomospecies $2(\operatorname{taxon} 9)$} \\
\hline F $141(=$ CCUG 15571)* & Horse, cavum oris & Denmark & \\
\hline $\mathrm{H} 4272 / 4^{*}$ & Horse, spleen & Australia & Blackall et al. $(1997,1998)$ \\
\hline KLM 96-146 & Horse & Sweden & M. Bisgaard (unpublished) \\
\hline F 124 & Horse, cavum oris & Denmark & \\
\hline F 192 & Horse, cavum oris & Denmark & \\
\hline F 193 & Horse, cavum oris & Denmark & \\
\hline \multicolumn{4}{|l|}{ Actinobacillus lignieresii } \\
\hline NCTC $4189^{\mathrm{T}}$ & Bovine, glands & UK & \\
\hline \multicolumn{4}{|l|}{ Actinobacillus genomospecies 1} \\
\hline F 126 & Horse, cavum oris & Denmark & \\
\hline F 127 (= CCUG 22229)* & Horse, cavum oris & Denmark & \\
\hline F 128 & Horse, cavum oris & Denmark & \\
\hline F 167 & Horse, cavum oris & Denmark & \\
\hline F $258(=$ CCUG 22230) & Horse, cavum oris & Denmark & \\
\hline F $264(=$ CCUG 22231)* & Horse, cavum oris & Denmark & \\
\hline F 429 & Horse, stomatitis & Denmark & \\
\hline C 5309b & Horse, stomatitis & Denmark & \\
\hline F $414(=6744 / 73)$ & Horse bite & Norway & Dibb et al. (1981) \\
\hline T $354 / 87$ & Horse bite & Australia & Peel et al. (1991) \\
\hline SSI P $1293^{*}$ & Horse bite (finger) & Denmark & \\
\hline
\end{tabular}

* 16S rRNA sequence determined.

\section{RESULTS AND DISCUSSION}

\section{Phenotypic characterization}

All strains of Bisgaard taxon 9 and A. lignieresii were found to be positive in the following tests: catalase, oxidase, fermentative reaction in Hugh-Leifson medium with $(+)$ D-glucose, porphyrin test, nitrate reduction, urease, alanine aminopeptidase, phosphatase, ONPG and production of acid from $(-)$ D-ribose, $(+) \mathrm{D}$-xylose, $(-) \mathrm{D}-\mathrm{mannitol},(-) \mathrm{D}-$ fructose, $(+) \mathrm{D}-$ galactose, $(+)$ D-glucose, $(+)$ D-mannose, lactose and sucrose.

Gram-staining was negative and negative results were obtained in the following tests: motility at 22 and $37^{\circ} \mathrm{C}$, symbiotic growth, $\beta$-haemolysis on bovineblood agar, Simmons citrate, mucate-acid, malonatebase, $\mathrm{H}_{2} \mathrm{~S}$ /tri-sugar iron (TSI), growth in the presence of $\mathrm{KCN}$, methyl red, Voges-Proskauer at $37^{\circ} \mathrm{C}$, production of gas from nitrate, arginine dihydrolase, lysine decarboxylase, ornithine decarboxylase, phenylalanine deaminase, indole production, gelatinase, hydrolysis of Tweens 20 and 80, pigment production, $\alpha$-glucosidase ( $p$-nitrophenyl $\alpha$-D-glucopyranoside; PNPG), $\beta$-glucosidase ( $p$-nitrophenyl $\beta$-D-glucopyranoside; NPG), $\alpha$-fucosidase (o-nitrophenyl $\alpha$-L-fucopyranoside; ONPF), $\alpha$-glucuronidase ( $p$-nitrophenyl $\beta$-D-glucopyranosiduronic acid; PGUA), $\alpha$-mannosidase, production of acid from $m$-erythritol, adonitol, $(+)$ D-arabitol, xylitol, $(-)$ L-xylose, dulcitol, $m$-inositol, $(+) \mathrm{D}-f u c o s e,(+) \mathrm{L}-\mathrm{rhamnose},(-) \mathrm{L}$-sorbose, cellobiose, trehalose, $(+) \mathrm{D}$-melezitose, $(+) \mathrm{D}$-glycogen, inulin, aesculin, amygdalin, arbutin, gentiobiose, salicin, (+)D-turanose and $\beta-N-\mathrm{CH}_{3}-$ glucosamid and formation of gas from $(+) \mathrm{D}$-glucose.

Characteristics that separate the taxa investigated are shown in Table 2. All strains identified as taxon 9 gave 
Table 2. Variable phenotypic characteristics of the equine isolates investigated

+ , All strains positive within 1-2 days; -, all strains negative after 14 days; $(+)$, all strains positive within 3-14 days; d, some strains positive; w, weakly positive. ONPX, $o$-Nitrophenyl $\beta$-D-xylanopyranoside.

\begin{tabular}{|c|c|c|c|c|c|}
\hline \multirow[t]{3}{*}{ Characteristic } & \multicolumn{2}{|c|}{ A. lignieresii } & \multicolumn{3}{|c|}{ Bisgaard taxon 9} \\
\hline & \multirow[t]{2}{*}{ NCTC $4189^{\mathrm{T}}$} & \multirow[t]{2}{*}{11 isolates } & \multirow{2}{*}{$\begin{array}{c}\text { Actinobacillus } \\
\text { genomospecies } 2 \text { (6 isolates) }\end{array}$} & \multicolumn{2}{|c|}{ A. arthritidis sp. nov. } \\
\hline & & & & CCUG $24862^{\mathrm{T}}$ & 11 isolates \\
\hline Growth on MacConkey's agar & - & $d$ & $d$ & - & $\mathrm{d}$ \\
\hline \multicolumn{6}{|l|}{ Fermentation of: } \\
\hline Glycerol & $\mathrm{w}$ & $+/(+)$ & $\mathrm{d}$ & $(+)$ & $\mathrm{d}$ \\
\hline$(+) \mathrm{L}-$ Arabinose & - & - & - & - & $\mathrm{d}$ \\
\hline$(-)$ D-Arabinose & - & $(+)$ & $\mathrm{d}$ & - & $\mathrm{d}$ \\
\hline (-)D-Sorbitol & - & - & - & + & + \\
\hline (-)L-Fucose & + & d & d & - & $\mathrm{d}$ \\
\hline Maltose & + & $+/(+)$ & $\mathrm{d}$ & + & $+/(+)$ \\
\hline$(+)$ D-Melibiose & - & - & $\mathrm{d}$ & $(+)$ & $+/(+)$ \\
\hline Raffinose & - & $(+)$ & + & + & + \\
\hline Dextrin & + & + & $+/(+)$ & + & $\mathrm{d}$ \\
\hline$\alpha$-Galactosidase & - & - & + & + & + \\
\hline$\beta$-Xylosidase (ONPX) & - & - & d & - & - \\
\hline
\end{tabular}

positive results in the $\alpha$-galactosidase and raffinose tests. With the exception of $\mathrm{H} 4272 / 4$, these strains were also positive in the $(+) \mathrm{D}$-melibiose test, and only two strains were found to be negative in the maltose test. Among the $(-)$ D-sorbitol-positive strains of taxon 9 , some strains were $(+)$ L-arabinose-positive, while all strains of $A$. lignieresii were negative for the characteristics listed in Table 2 with the exception of raffinose and maltose.

\section{Serotyping}

The three A. lignieresii strains F 127, SSI P 1293 and F 264 were typable as serotype 3 by using reference sera for $A$. pleuropneumoniae, while the other equine strains of $A$. lignieresii were untypable by this method.

\section{$16 S$ rRNA sequence comparison}

For the four strains of taxon 9 investigated (Table 1), the sequences from E. coli rrnB positions 29-1481 were obtained, with lengths of $1461 \mathrm{nt}$. The 16S rRNA sequence of strain CCUG $24862^{\mathrm{T}}$ was found to be $100 \%$ similar to the published sequence (accession no. L06084). For strains F 127 and F 264 of A. lignieresii, the sequences at positions $17-1507$ and $28-1500$ were obtained with respective lengths of 1489 and $1470 \mathrm{nt}$. The sequence of strain SSI P 1293 was identical to that of strain F 127, and only the latter strain was included in the analysis.

The phylogenetic tree (Fig. 1) is based on the seven sequences determined in the present study, seven unpublished sequences of Bisgaard taxon 11 and $A$. equuli (deposited with GenBank) and published sequences of genuine actinobacilli. The sequence with accession number M75073 was left out, since it was found previously not to represent the strain reported (Hedegaard et al., 2001). The tree was found to be highly consistent across the different methods used for phylogenetic reconstruction. Of the 19 nodes of the maximum-likelihood tree, 17, 11 and 10 nodes were also supported by parsimony, neighbour-joining and by bootstrap values higher than $50 \%$, respectively. $A$. lignieresii, the type species of the genus, and $A$. pleuropneumoniae were closely related and more distantly related to taxon 8 . This group did not contain equine strains. Two strains of taxon 9 representing the (-)D-sorbitol-negative group (F 141 and H 4272/4) were closely related, having $99.5 \% 16 \mathrm{~S}$ rRNA sequence similarity. A high degree of consistency was found for the node joining these strains and A. hominis. Strains F 141 and $\mathrm{H} \mathrm{4272/4}$ were related to the type strain of $A$. hominis, showing $98 \cdot 2-98.5 \%$ similarity. The similarity between strains CCUG $24862^{\mathrm{T}}$ and $13 / 225 / 95$ of the $(-) \mathrm{D}$-sorbitol-positive group was $99.6 \%$, and these strains were related to the $(-) \mathrm{D}-$ sorbitol-negative group, showing 97.7-97.9\% similarity. The two strains of the $(-)$ D-sorbitol-positive group were related to $A$. ureae, having $98 \cdot 0-98 \cdot 3 \%$ similarity and a common node in the phylogenetic analysis.

The similarity between strains F 127 and F 264 of $A$. lignieresii was $98.5 \%$. Surprisingly, a high degree of divergence was found between strains $\mathrm{F} 127$, SSI P 1293 and F 264 of $A$. lignieresii and the type strain of 


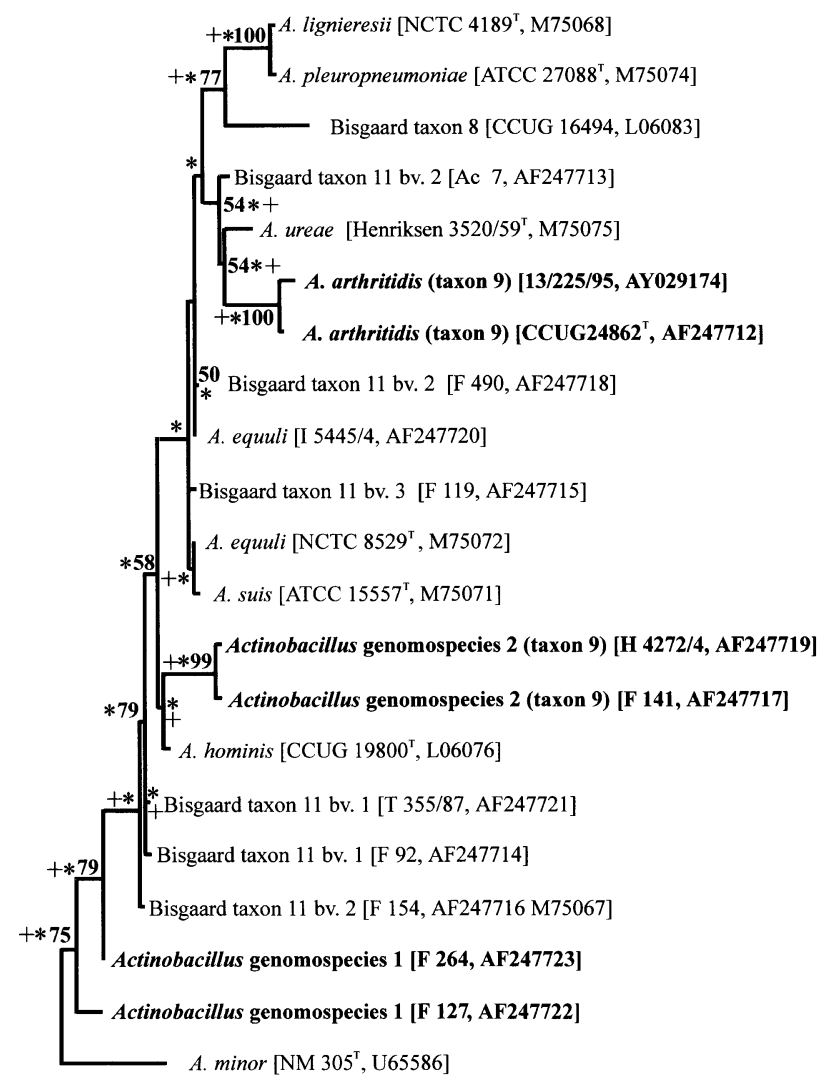

0.01 evolutionary distance

Fig. 1. Phylogenetic relationships between strains of selected taxa associated with horses and published sequences of genuine actinobacilli, with Actinobacillus minor included as an outgroup, based on maximum-likelihood analysis of $16 \mathrm{~S}$ rRNA sequences. Significances of specific nodes obtained in bootstrap analysis are indicated for values higher than $50 \%$. Nodes supported in phylogenetic trees obtained by neighbour-joining and parsimony methods are indicated by + and *, respectively. Strains sequenced in the present study are shown in bold. bv., Biovar.

this species, there being only $96 \cdot 4-96.7 \%$ similarity. The highest similarities observed between strains $F$ 127, SSI P 1293 and F 264 and the strains of Actinobacillus investigated were $98 \cdot 6-98 \cdot 8 \%$, to strains F 92, F 154 and T 355/87 of Bisgaard taxon 11. The lowest similarities observed between strains F 127, SSI P 1293 and F 264 and the strains of Actinobacillus investigated were $96 \cdot 0-96 \cdot 2 \%$, to the type strain of $A$. pleuropneumoniae, strain CCUG 16494 of Bisgaard taxon 8 and strains CCUG $24862^{\mathrm{T}}$ and $13 / 225 / 95$ of Bisgaard taxon 9.

Comparison of $16 \mathrm{~S}$ rRNA sequences showed that equine actinobacilli tentatively classified as A. lignieresii and taxon 9 of Bisgaard were located in three novel groups among the genuine actinobacilli. These organisms were formerly included in cluster 4A and partly in cluster 4B by Dewhirst et al. (1993). According to
Mutters et al. (1989), genuine actinobacilli are defined as including $A$. equuli, $A$. hominis, A. lignieresii, $A$. pleuropneumoniae, $A$. suis, $A$. ureae and taxa 9 and 11 of Bisgaard, and 16S rRNA sequence data include Bisgaard taxon 8 but exclude A. capsulatus, A. minor and Bisgaard taxon 5, as these taxa do not form a consistent monophyletic group with the first eight taxa (Dewhirst et al., 1993; Foster et al., 1996, 1998).

The mean 16S rRNA sequence difference between type strains of species belonging to the genera Pasteurella and Actinobacillus, as defined by DNA-DNA hybridizations, is respectively 7.0 and $5.0 \%$ (Angen et al., 1999). The mean sequence difference between a representative from each of the five 16S rRNA clusters of the newly proposed genus Mannheimia was $3.4 \%$. The exclusion of A. capsulatus and Bisgaard taxon 5 from the genus Actinobacillus, as defined by DNA-DNA hybridization (Mutters et al., 1989), and of A. minor, on the basis of 16S rRNA analysis (Foster et al., 1998), would reduce the mean sequence difference between species of Actinobacillus to $1.7 \%$. Redefinition of the genus Pasteurella to include only cluster 3B of Dewhirst et al. (1993), and the formation of a new genus to include the avian taxa of cluster $3 \mathrm{~A}$, would result in mean sequence differences for these tentative new genera (respectively 2.9 and $1.7 \%$ ) that are at approximately the same level as for Actinobacillus. The mean variation between $16 \mathrm{~S}$ rRNA sequences of genuine actinobacilli increases to $2 \cdot 3 \%$ with inclusion of the three taxa described in the present study. The variations between $16 \mathrm{~S}$ rRNA sequences within species of genuine actinobacilli would then vary from $0.3 \%$ (type strains of $A$. pleuropneumoniae and A. lignieresii) to $4.0 \%$ (strain $13 / 225 / 95$ of Bisgaard taxon 9 and strain F 127 of $A$. lignieresii). Low variation has also been reported for other species (Vandamme et al., 1996), and no definitive limits for the separation of species on the basis of 16S rRNA sequence variation can be drawn (Stackebrandt \& Goebel, 1994; Vandamme et al., 1996).

\section{DNA-DNA hybridization}

DNA-DNA hybridization between the two strains representing the $(-)$ D-sorbitol-negative group of taxon 9 showed $98 \%$ binding; the closest relationship $(64 \%)$ was to a strain of $A$. lignieresii. A full DNAbinding matrix is available as supplementary material in IJSEM Online (http://ijs.sgmjournals.org/). The two strains of the $(-)$ D-sorbitol-positive group of taxon 9 showed $83 \%$ binding and were related to the $(-)$ D-sorbitol-negative group $(72-76 \%$ DNA binding). DNA-DNA hybridization between the two equine strains of $A$. lignieresii showed $92 \%$ binding, but there was only $70-72 \%$ binding to the type strain of $A$. lignieresii (see supplementary material). Consequently, these equine isolates of $A$. lignieresii represent a novel genomospecies of Actinobacillus, since phenotypic characteristics are not presently available to separate them from the type strain of $A$. lignieresii. 
Species identification and separation is based on DNA -DNA hybridizations and sufficient phenotypic variation to allow identification by biochemical characterization (Vandamme et al., 1996). The final decision about the classification of Actinobacillus sensu stricto must await further DNA-DNA hybridization experiments. For the same reason, precise limits of DNA binding for separation of Actinobacillus species cannot be given at present. The results of our study have shown a limit of around $80 \%$, which is slightly lower than that for the genus Mannheimia and for other species of the family, for which a limit of $85 \%$ has been set (Angen et al., 1999; Mutters et al., 1989).

In the present work, it has been shown that Bisgaard taxon 9 represents two novel species, supported by DNA-DNA hybridization. The 16S rRNA sequence comparison showed the (-)D-sorbitol-positive group to be related to $A$. ureae; however, DNA binding between strain CCUG $24862^{\mathrm{T}}$ of the $(-) \mathrm{D}$-sorbitolpositive group and the type strain of $A$. ureae was only $44 \%$ (Escande et al., 1984), indicating that the close relationship obtained by the phylogenetic analysis of $16 \mathrm{~S}$ rRNA sequences was not reflected in the level of total DNA similarity. Further DNA-DNA hybridization experiments were not performed because of the low degree of DNA binding to the taxa most closely related in terms of $16 \mathrm{~S}$ rRNA sequence. The $(-) \mathrm{D}-$ sorbitol-negative group was related to A. hominis in the 16S rRNA sequence comparison; however, DNADNA binding between the type strain of $A$. hominis and strain CCUG 15571 of Bisgaard taxon 9 has recently been reported to be only $50 \%$ (Friis-Møller et al., 2001).

The name Actinobacillus arthritidis sp. nov. is proposed in the final classification of Bisgaard taxon 9. $A$. arthritidis is positive for fermentation of $(-) \mathrm{D}$-sorbitol, while Actinobacillus genomospecies 2 is negative. Characteristics exist for the phenotypic separation of Actinobacillus genomospecies 2 from other phenotypically related species of actinobacilli. For example, $A$. arthritidis and $A$. lignieresii are trehalose-negative, while A. equuli and taxon 11 are positive. A. arthritidis, $A$. equuli and taxon 11 are $\alpha$-galactosidase-positive, while $A$. lignieresii is negative. Most strains of $A$. arthritidis are (-)L-fucose-positive, like $A$. lignieresii, while $A$. equuli and taxon 11 are (-)L-fucose-negative. Finally, most strains of the novel species are $(+) \mathrm{D}-$ melibiose-positive, like $A$. equuli and taxon 11, while all strains of $A$. lignieresii are $(+) \mathrm{D}$-melibiose-negative (see Table 2 and Bisgaard et al., 1984).

Three equine strains of $A$. lignieresii were serotyped as A. pleuropneumoniae serotype 3 . This could have been related to the high similarity between these two species, since $A$. lignieresii can only be separated phenotypically from $A$. pleuropneumoniae biovar 2 by being non-haemolytic. However, the $16 \mathrm{~S}$ rRNA sequences of these strains show low similarities to the type strains of $A$. lignieresii and $A$. pleuropneumoniae, and it is concluded that serotyping is not a reliable method for the separation of these species. These equine isolates of $A$. lignieresii represent a novel species with respect to both 16S rRNA sequence data and DNA binding; however, phenotypic characteristics needed for identification were not found. For this reason, we refrain from naming this taxon. The low degree of $16 \mathrm{~S}$ rRNA sequence similarity between bovine and equine strains of $A$. lignieresii was also reflected by DNA-DNA hybridization. Earlier investigations have shown $95 \%$ DNA binding between two bovine strains of $A$. lignieresii (Borr et al., 1991; Pohl et al., 1983), while only $70 \%$ DNA binding was found between an equine isolate and a bovine isolate in the present study.

\section{Description of Actinobacillus arthritidis sp. nov.}

Actinobacillus arthritidis (ar.thri'ti.dis. N.L. fem. gen. n. arthritidis of arthritis, from Gr. n. árthron joint; L. suffix -itis used in names of inflammations).

The species is positive in the following tests: catalase, oxidase, fermentative reaction in Hugh-Leifson medium with $(+)$ D-glucose, porphyrin test, nitrate reduction, urease, alanine aminopeptidase, phosphatase, ONPG, $\alpha$-galactosidase and production of acid from $(-)$ D-ribose, $(+)$ D-xylose, $(-)$ D-mannitol, $(-)$ D-sorbitol, (-)D-fructose, (+)D-galactose, (+)D-glucose, $(+)$ D-mannose, lactose, sucrose and raffinose. Negative results are obtained in the following tests: Gramstaining (pleomorphic without distinctive morphology), motility at 22 and $37^{\circ} \mathrm{C}$, symbiotic growth, $\beta$ haemolysis, Simmons citrate, mucate-acid, malonatebase, $\mathrm{H}_{2} \mathrm{~S}$ /TSI, growth in the presence of $\mathrm{KCN}$, methyl red and Voges-Proskauer at $37^{\circ} \mathrm{C}$, production of gas from nitrate, arginine dihydrolase, lysine decarboxylase, ornithine decarboxylase, phenylalanine deaminase, indole production, gelatinase, hydrolysis of Tweens 20 and 80, pigment production, $\alpha$-glucosidase (PNPG), $\beta$-glucosidase (NPG), $\alpha$-fucosidase (ONPF), $\alpha$-glucuronidase (PGUA), $\alpha$-mannosidase, $\beta$-xylosidase, production of acid from $m$-erythritol, adonitol, $(+)$ D-arabitol, xylitol, $(-) \mathrm{L}$-xylose, dulcitol, $m$-inositol, $(+)$ D-fucose, $(+)$ L-rhamnose, $(-)$ L-sorbose, cellobiose, trehalose, $(+) \mathrm{D}-$ melezitose, $(+) \mathrm{D}-\mathrm{glycogen}$, inulin, aesculin, amygdalin, arbutin, gentiobiose, salicin, (+)D-turanose and $\beta$ - $\mathrm{N}-\mathrm{CH}_{3}$-glucosamid and formation of gas from $(+) \mathrm{D}$-glucose. Characteristics that show variation are listed in Table 2. On bovineblood agar, the colonies are non-haemolytic, circular, raised and regular with entire margins. The surface of the colonies is generally smooth, shiny, greyish and non-transparent. Mucoid or watery cultures also exist. A diameter of $2-3 \mathrm{~mm}$ is often observed after $24 \mathrm{~h}$ aerobic incubation at $37^{\circ} \mathrm{C}$. Strains have been isolated from the oral cavities of apparently healthy horses, as well as from diseased foals or horses (mainly those with septicaemia and arthritis) (Table 1).

The type strain, CCUG $24862^{\mathrm{T}}\left(=\mathrm{ATCC} 13376^{\mathrm{T}}=\right.$ Wetmore $1706^{\mathrm{T}}$ ), was isolated from a joint of a horse. 


\section{ACKNOWLEDGEMENTS}

Gitte Frederiksen, Stina Holm and Sanne Laulund are thanked for technical assistance. Dr Sten Ebbesen, Institute for Greek and Latin, University of Copenhagen, Denmark, is thanked for help with the Latin names. The study was financed by the Danish Agricultural and Veterinary Research Council (grant no. 9702797).

\section{REFERENCES}

Angen, Ø., Aalbæk, B., Falsen, E., Olsen, J. E. \& Bisgaard, M. (1997). Relationships among strains classified with the ruminant Pasteurella haemolytica-complex using quantitative evaluation of phenotypic data. Zentbl Bakteriol 285, 459-479.

Angen, Ø., Mutters, R., Caugant, D. A., Olsen, J. E. \& Bisgaard, M. (1999). Taxonomic relationships of the [Pasteurella] haemolytica complex as evaluated by DNA-DNA hybridizations and 16S rRNA sequencing with proposal of Mannheimia haemolytica gen. nov., comb. nov., Mannheimia granulomatis comb. nov., Mannheimia glucosida sp. nov., Mannheimia ruminalis sp. nov. and Mannheimia varigena sp. nov. Int J Syst Bacteriol 49, 67-86.

Ashhurst-Smith, C., Norton, R., Thoreau, W. \& Peel, M. M. (1998). Actinobacillus equuli septicemia: an unusual zoonotic infection. $J$ Clin Microbiol 36, 2789-2790.

Baum, K. H., Shin, S. J., Rebhun, W. C. \& Patten, V. H. (1984). Isolation of Actinobacillus lignieresii from enlarged tongue of a horse. $J$ Am Vet Med Assoc 185, 792-793.

Biberstein, E. L. (1981). Haemophilus-Pasteurella-Actinobacillus: their significance in veterinary medicine. In Haemophilus, Pasteurella and Actinobacillus, pp. 61-73. Edited by M. Kilian, W. Frederiksen \& E. L. Biberstein. London: Academic Press.

Bisgaard, M. (1993). Ecology and significance of Pasteurellaceae in animals. Zentbl Bakteriol 279, 7-26.

Bisgaard, M. (1995). Taxonomy of the family Pasteurellaceae Pohl 1981. In Haemophilus, Actinobacillus and Pasteurella, pp. 1-7. Edited by W. Donachie, F. A. Lawson \& J. C. Hodgson. New York: Plenum.

Bisgaard, M., Piechulla, K., Ying, Y.-T., Frederiksen, W. \& Mannheim, W. (1984). Prevalence of organisms described as Actinobacillus suis or haemolytic Actinobacillus equuli in the oral cavity of horses. Comparative investigations of strains obtained and porcine strains of A. suis sensu stricto. Acta Pathol Microbiol Immunol Scand Sect B 92, 291-298.

Bisgaard, M., Phillips, J. E. \& Mannheim, W. (1986). Characterization and identification of bovine and ovine Pasteurellaceae isolated from the oral cavity and rumen of apparently normal cattle and sheep. Acta Pathol Microbiol Immunol Scand Sect B 94, 9-17.

Bisgaard, M., Houghton, S. B., Mutters, R. \& Stenzel, A. (1991). Reclassification of German, British and Dutch isolates of so-called Pasteurella multocida obtained from pneumonic calf lungs. Vet Microbiol 26, 115-124.

Blackall, P. J., Bisgaard, M. \& McKenzie, R. A. (1997). Characterisation of Australian isolates of Actinobacillus capsulatus, Actinobacillus equuli, Pasteurella caballi and Bisgaard taxa 9 and 11. Aust Vet $J$ 75, 52-55.

Blackall, P. J., Christensen, J. P. \& Bisgaard, M. (1998). Diversity among isolates of Actinobacillus equuli and related organisms as revealed by ribotyping. Aust Vet J 76, 423-425.

Borr, J. D., Ryan, D. A. J. \& Maclnnes, J. I. (1991). Analysis of Actinobacillus pleuropneumoniae and related organisms by DNA-DNA hybridization and restriction endonuclease fingerprinting. Int $J$ Syst Bacteriol 41, 121-129.

Chladek, D. W. \& Ruth, G. R. (1976). Isolation of Actinobacillus lignieresii from an epidural abscess in a horse with progressive paralysis. $J$ Am Vet Med Assoc 168, 64-66.

Christensen, H., Angen, Ø., Mutters, R., Olsen, J. E. \& Bisgaard, M. (2000). DNA-DNA hybridization determined in micro-wells using covalent attachment of DNA. Int J Syst Evol Microbiol 50, 1095-1102. Christensen, H., Bisgaard, M. \& Olsen, J. E. (2002). Reclassification of equine isolates previously reported as Actinobacillus equuli, variants of A. equuli, Actinobacillus suis or Bisgaard taxon 11 and proposal of A. equuli: A. equuli subsp. equuli subsp. nov. and $A$. equuli subsp. haemolyticus subsp. nov. Int J Syst Evol Microbiol 52 (in press).

Dewhirst, F. E., Paster, B. J. \& Bright, P. L. (1989). Chromobacterium, Eikenella, Kingella, Neisseria, Simonsiella, and Vitreoscilla species comprise a major branch of the beta group Proteobacteria by $16 \mathrm{~S}$ ribosomal ribonucleic acid sequence comparison: transfer of Eikenella and Simonsiella to the family Neisseriaceae (emend.). Int J Syst Bacteriol 39, 258-266.

Dewhirst, F. E., Paster, B. J., Olsen, I. \& Fraser, G. J. (1993). Phylogeny of the Pasteurellaceae as determined by comparison of $16 \mathrm{~S}$ ribosomal ribonucleic acid sequences. Zentbl Bakteriol 279, 35-44.

Dibb, W. L., Digranes, A. \& Tønjum, S. (1981). Actinobacillus lignieresii infection after a horse bite. Br Med J 283, 583-584.

Escande, F., Grimont, F., Grimont, P. A. D. \& Bercovier, H. (1984). Deoxyribonucleic acid relatedness among strains of Actinobacillus spp. and Pasteurella ureae. Int J Syst Bacteriol 34, 309-315.

Felsenstein, J. (1981). Evolutionary trees from DNA sequences: a maximum likelihood approach. J Mol Evol 17, 368-376.

Felsenstein, J. (1995). PHYLIP (Phylogeny Inference Package) version 3.5c. Seattle: University of Washington.

Foster, G., Ross, H. M., Malnick, H., Willems, A., Garcia, P., Reid, R. J. \& Collins, M. D. (1996). Actinobacillus delphinicola sp. nov., a new member of the family Pasteurellaceae Pohl (1979) 1981 isolated from sea mammals. Int $J$ Syst Bacteriol 46, 648-652.

Foster, G., Ross, H. M., Patterson, I. A. P., Hutson, R. A. \& Collins, M. D. (1998). Actinobacillus scotiae sp. nov., a new member of the family Pasteurellaceae Pohl (1979) 1981 isolated from porpoises (Phocoena phocoena). Int J Syst Bacteriol 48, 929-933.

Friis-Møller, A., Christensen, J. J., Fussing, V., Hesselbjerg, A.-H., Christiansen, J. \& Bruun, B. (2001). Clinical significance and taxonomy of Actinobacillus hominis. J Clin Microbiol 39, 930-935.

Giese, S. B., Stenbæk, E. \& Nielsen, R. (1993). Identification of Actinobacillus pleuropneumoniae serotype 2 by monoclonal or polyclonal antibodies in latex agglutination tests. Acta Vet Scand 34, 223-225.

Hedegaard, J., Okkels, H., Bruun, B., Kilian, M., Mortensen, K. K. \& Nørskov-Lauritsen, N. (2001). Phylogeny of the genus Haemophilus as determined by comparison of partial infB sequences. Microbiology 147, 2599-2609.

Jang, S. S., Biberstein, E. L. \& Hirsch, D. C. (1987). Actinobacillus suis-like organisms in horses. Am J Vet Res 48, 1036-1038.

Leisner, J. J., Pot, B., Christensen, H., Rusul, G., Olsen, J. E., Wee, B. W., Muhamad, K. \& Ghazali, H. M. (1999). Identification of lactic acid bacteria from chili bo, a Malaysian food ingredient. Appl Environ Microbiol 65, 599-605.

Mohan, K., Muvavarirwa, P. \& Pawandiwa, A. (1997). Strains of Actinobacillus spp. from diseases of animals and ostriches in Zimbabwe. Onderstepoort J Vet Res 64, 195-199.

Mutters, R., Mannheim, W. \& Bisgaard, M. (1989). Taxonomy of the group. In Pasteurella and Pasteurellosis, pp. 3-34. Edited by C. Adlam \& J. M. Rutter. London: Academic Press.

Olsen, G. J., Matsuda, H., Hagstrom, R. \& Overbeek, R. (1994). fastDNAml: a tool for construction of phylogenetic trees of DNA sequences using maximum likelihood. Comput Appl Biosci 10, 41-48.

Paster, B. J. \& Dewhirst, F. E. (1988). Phylogeny of campylobacters, wolinellas, Bacteroides gracilis, and Bacteroides ureolyticus by $16 \mathrm{~S}$ ribosomal ribonucleic acid sequencing. Int J Syst Bacteriol 38, 56-62.

Peel, M. M., Hornidge, K. A., Luppino, M., Stacpoole, A. M. \& Weaver, R. E. (1991). Actinobacillus spp. and related bacteria in infected wounds of humans bitten by horses and sheep. J Clin Microbiol 29, 2535-2538.

Pohl, S., Bertschinger, H. U., Frederiksen, W. \& Mannheim, W. (1983). Transfer of Haemophilus pleuropneumoniae and the Pasteurella haemolytica-like organisms causing porcine necrotic pleuropneumonia to the genus Actinobacillus (Actinobacillus pleuropneumoniae comb. 
nov.) on the basis of phenotypic and deoxyribonucleic acid relatedness. Int J Syst Bacteriol 33, 510-514.

Samitz, E. M. \& Biberstein, E. L. (1991). Actinobacillus suis-like organisms and evidence of hemolytic strains of Actinobacillus lignieresii in horses. Am J Vet Res 52, 1245-1251.

Stackebrandt, E. \& Goebel, B. M. (1994). Taxonomic note: a place for DNA-DNA reassociation and 16S rRNA sequence analysis in the present species definition in bacteriology. Int J Syst Bacteriol 44, 846-849.

Sternberg, S. \& Brändström, B. (1999). Biochemical fingerprinting and ribotyping of isolates of Actinobacillus equuli from healthy and diseased horses. Vet Microbiol 66, 53-65.

Vandamme, P., Pot, B., Gillis, M., De Vos, P., Kersters, K. \& Swings,
J. (1996). Polyphasic taxonomy, a consensus approach to bacterial systematics. Microbiol Rev 60, 407-438.

Vogel, B. F., Jørgensen, K., Christensen, H., Olsen, J. E. \& Gram, L. (1997). Differentiation of Shewanella putrefaciens and Shewanella alga on the basis of whole-cell protein profiles, ribotyping, phenotypic characterization, and 16S rRNA gene sequence analysis. Appl Environ Microbiol 63, 2189-2199.

Ward, C. L., Wood, J. L. N., Houghton, S. B., Mumford, J. A. \& Chanter, N. (1998). Actinobacillus and Pasteurella species isolated from horses with lower airway disease. Vet Rec 143, 277-279.

Zaharija, I.., Modric, Z. \& Naglic, T. (1979). Spontaneous infection with Actinobacillus lignieresii in horses: study of the first case in Croatia. Vet Arh 49, 105-112. 